\title{
COMPARATIVE STUDY BETWEEN PEATMOSS AND RICE STRAW AS A NURSERY MEDIA
}

\author{
EL- MOULA, MANAL M. H. GAD ${ }^{1}$, A.A. FARAG ${ }^{1}$, MONA A. M. ALY ${ }^{1}$, \\ YOUNS.T.M.M. ${ }^{1}$ and A. SCHUCH ${ }^{2}$
}

1. Central Laboratory for Agricultural Climate- ARC, Giza

2. University of Rostock, Faculty of Agricultural and Environmental, Department of Waste Management and Material Flow (Germany)

(Manuscript received 20 November 2016)

\begin{abstract}
$\mathrm{T}$

his study was carried out to investigate the possibility of using cut rice straw, as organic nursery media, compared to the traditional peatmoss, to produce seedlings for beans, cucumber, tomatoes, cantaloupe, zucchini, cabbage and lettuce. The experimental design was five treatments with three replicates each. The used substrates were the traditional peatmoss and vermiculite $1: 1(\mathrm{v} / \mathrm{v})$ compared with mixtures between the traditional substrate and different percentage of cut rice straw $(<2$ $\mathrm{mm})$, from $25 \%$ up to $100 \%(\mathrm{v} / \mathrm{v})$. The following parameters were measured: seedling dry weight, seedling fresh weight, seedling stem diameter, length of seedling, seedling leaf area, number of leaves, and nutrient content of the seedlings (NPK). Results revealed that the best treatment was the mixture of $50 \%$ traditional nursery substrate and the $50 \%$ rice straw mixture with traditional nursery substrate. It was concluded that cut rice straw could be used as an organic nursery media mixed with traditional one. This will help reducing environmental pollution caused by burning the huge amount of rice straw every year in Egyptian farms.

Key words: Rice straw, peat moss, nursery substrate, seedling plate, bean, cucumber, tomato, cantaloupe, zucchini, cabbage, lettuce, mixture, seedling.
\end{abstract}

\section{INTRODUCTION}

A nursery area considered as a place where plants well managed during the early stages of growth, providing optimum conditions for seeds germination and subsequent growth, until they are strong enough to be transplanted in the permanent field. Peat materials are common media in most of the world. However, peat is obtained from wetlands, which are being rapidly depleted, causing environmental problems. Many countries are warning peat mining and prices are increasing as a result of increasing international demand. Since the last two decades, research on peat alternatives has been intense and will continue being of great interest in the future (Wilson et al., 2006). According to Hartmann et al. (2007), seeds germination is influenced by many factors such as type of substrate used, environmental factors such 
as oxygen, water, and temperature. Generally, growth media has been adjudged to be the most critical factor determining seedling quality in the nursery (Baiyeri and Mbah, 2006). The growth media physical properties can also have a profound effect on the supply of water and air to the growing plant (Baiyeri, 2005).

Rice straw has several attributes which is basic to make good media. It has good water holding capacity and air porosity for good root growth. Compared with peat moss media, Rice straw has low transported costs. Rice straw material characteristics media suitable for agriculture cultivation, low salinity content, also could be easy stored almost, free from pathogens, pests and weed seeds which might cause disease or reduce plant growth. Straw is the only organic material available in huge quantities at most of farms in Egypt. Rice straw in the dry matter contains nutrients as nitrogen (N)40\%, phosphorus (P)30-35\%, potassium (K)80-85\% and sulfur (S)40-50\% which taken up while the rice cultivation (Dobermann and Fairhurst, 2002).

Hassan (2005) reported that a $30 \%$ addition of rice straw compost in tomato grown in a peat-based transplant media showed an increased plant dry biomass, fruit diameter, yields and water use efficiency. on-farm media produced by composting of natural materials such as water lettuce, and rice straw is an approach available to farmers to replace the use of more expensive commercial media. Can be introduced to organic farmers as an alternative method to prepare growing media with the use of locally available organic amendments (Manenoi et al., (2009). The use of composted rice straw, poultry manure and banana waste mixed with peat moss, showed improved growth of tomato seegling ( Badran et al., 2007 ).

The aim of this study was to evaluate the effect of partial peat substitution by alternatives, such as catted rice straw for seeds germination and quality for some vegetables seedlings.

\section{MATERIALS AND METHODS}

The study was conducted at the experimental site of the Central Laboratory for Agricultural Climate (CLAC), Dokki, Giza, Egypt. the experiment was carried out to study the possibilities of using rice straw as organic growing media which is consider a cheap material than peatmossin, in order to produce vegetable seedlings such as bean (Phaseolus|vulgaris), cucumber (Cucumissativus), tomato (Lycopersicon esculentum) , cantaloupe (C. melo var. cantalupensis), zucchini (Cucurbitapepo), cabbage (Brassica oleracea var. capitata) and lettuce (Lactuca sativa). The experiment design was five treatments and three replicates. The seeds 
for each treatment were planted in trays which are filled with two different mixtures. The two media were as follow:

1- Mixture nursery 1 (traditional nursery mixture):

Peatmoss and vermiculite $(1: 1 \mathrm{v} / \mathrm{v})$

2- Mixture nursery 2 (suggested nursery mixture):

In this mixture, the peat moss in the traditional mixture was replaced with a chopped rice straw $(<2 \mathrm{~mm})$. The main five treatments:

a- $\quad 100 \%$ (Mixture nursery 1 ) $\rightarrow$ T1

b- $\quad 75 \%$ (Mixture nursery1) $+25 \%$ (Mixture nursery2) $\rightarrow \mathrm{T} 2$

c- $\quad 50 \%$ (Mixture nursery 1 ) $+50 \%$ (Mixture nursery2) $\rightarrow \mathrm{T} 3$

d- $\quad 25 \%$ (Mixture nursery1) $+75 \%$ (Mixture nursery2) $\rightarrow$ T4

e- $\quad 100 \%$ (Mixture nursery2) $\rightarrow$ T5

Both mixture nursery contain. ammonium sulphate $(250-300 \mathrm{~g} / 450 \mathrm{~L})$, potassium sulphate (300-400 g/450 L), calcium super phosphate (200-250 g/450 L), a mixture of micronutrients $(50-70 \mathrm{~g} / 450 \mathrm{~L})$, chemical fungicides (Penlight, Vetafax, Kapetan, Rizolex $50 \mathrm{~g} / 450 \mathrm{~L}$ ) and calcium carbonate $(4 \mathrm{Kg} / 450 \mathrm{~L})$. (Agriculture Extension Bulletin (1993).

Table (1) shows the seeding dates and the number of days after seeding for each crop.

Table 1. Seeding date and days even after seeding for each crop.

\begin{tabular}{|l|c|c|}
\hline \multicolumn{1}{|c|}{ Crop name } & Seeding dates & $\begin{array}{c}\text { Number of days after } \\
\text { seeding }\end{array}$ \\
\hline Bean & $1 / 10$ in 2012 and 2013 & 25 \\
\hline Cucumber, cantaloupe, zucchini & $3 / 10$ in 2012 and 2013 & 30 \\
\hline Tomato & $15 / 11$ in 2012 and 2013 & 45 \\
\hline Cabbage & $1 / 12$ in 2012 and 2013 & 45 \\
\hline Lettuce & $15 / 10$ in 2012 and2013 & 30 \\
\hline
\end{tabular}

The main chemical analysis of the two organic media were peatmoss and chopped rice straw are shown in Table (2).

Table 2. Chemical composition of the organic media.

\begin{tabular}{|l|c|c|c|c|c|c|}
\hline Organic media & $\begin{array}{c}\text { Organic } \\
\text { carbon\% }\end{array}$ & $\begin{array}{c}\text { Total } \\
\text { Nitrogen\% }\end{array}$ & $\begin{array}{c}\mathrm{pH} \\
1: 2.5\end{array}$ & $\begin{array}{c}\mathrm{EC} \\
\mathrm{ds} / \mathrm{m}\end{array}$ & phosphorous(ppm) & $\begin{array}{c}\text { potassium } \\
(\mathrm{ppm})\end{array}$ \\
\hline Peatmoss & 45 & 0.56 & 6.3 & 0.32 & 20 & 780 \\
\hline Rice straw & 84 & 0.64 & 6.4 & 1.18 & 0.78 & 0.83 \\
\hline
\end{tabular}




\section{Vegetative measurements of the seedlings:}

Dry weight - Fresh weight - Stem diameter - Length of seedling - leaf Area- Number of leaves.

\section{Chemical analyses of the seedling:}

Dry weight (gm) per plant leaves and shoots were dried at $70 \mathrm{C}$ temperature degree to a constant weight and the dry weight per plant was calculated.

Total nitrogen (\%) in leaves was determined by using the micro kjeldahl by A.O.A.C. (1991).

Phosphorus (\%) was determined calorimetrically at $550 \mathrm{~mm}$ as described by Ranganna (1979). Potassium (\%) was determined by flame photometer as described by Ranganna (1979).

Statistical analysis: The experiment was laid out in randomized completed block design (RCBD) with three replicates and five treatments. The treatments (five seedling medias) were arranged randomly in each replicate for each crop.

Data were subjected to statistical analysis using the analysis of variance method; the means of treatments were compared using the least significant difference (L.S.D.) at 0.05 level of probability according to Snedecor and Cochran (1980).

\section{RESULTS AND DISCUSSION}

Data in Table (3) indicate that the effect of rice straw media on seeds germination percentage, especially for bean, cucumber, tomato, cantaloupe, zucchini, cabbage and lettuce. The germination of all crops was not affected by mixture of rice straw media. Seeds germination of all crops were delayed 3 days when seeds placed in rice straw media. Seedlings growth percentage relay on mixture media. The best mixture of rice straw media was (T3) $[50 \%$ (nursery 1$)+50 \%$ (nursery 2 ) $]$ this mixture obtain the highest percentage of seeds germination.

Table3. Effect of rice straw media on seeds germination percentage.

\begin{tabular}{|c|c|c|c|c|c|c|c|}
\hline Treatment & Bean & Cucumber & Tomato & Cantaloupe & Zucchini & Cabbage & Lettuce \\
\hline & \multicolumn{7}{|c|}{ Germination percentage (\%) } \\
\hline T1 & 99 & 100 & 100 & 98 & 97 & 100 & 99 \\
\hline T2 & 98 & 97 & 97 & 98 & 96 & 97 & 98 \\
\hline T3 & 99 & 100 & 100 & 98 & 97 & 100 & 99 \\
\hline T4 & 85 & 88 & 90 & 86 & 88 & 89 & 90 \\
\hline T5 & 82 & 87 & 89 & 85 & 86 & 87 & 89 \\
\hline L.S.D & NS & NS & NS & NS & NS & NS & NS \\
\hline
\end{tabular}

NS = not significant 
Data presented in Table (4) show that, there were significant differences among using different mixtures of rice straw media and peatmoss nursery media on bean seedling growth parameters after 25 days from seeding date, especially on fresh weight. The highest fresh weight of crop seedling was obtained by T3 in the two seasons andT1 higher fresh weight than other treatment. However, the lowest value was found inT4 and T5with increasing the rice straw in the mixture over $50 \%$, due to that plant fresh weight has been decreased. The stimulated characters indicated that, rice straw possibly contain stimulator substances which reflected this response. This agrees with Rizk et al. (2005) reported that, undiluted rice straw of Sakha 102 cultivar, increased significantly fresh weight of squash seedling.

Table 4. Effect of different mixtures of rice straw media and peat moss nursery media on fresh weight of crop seedlings.

\begin{tabular}{|c|c|c|c|c|c|c|c|}
\hline \multirow{3}{*}{ Treatment } & \multicolumn{7}{|c|}{ First Season } \\
\hline & Bean & Cucumber & Tomato & Cantaloupe & Zucchini & Cabbage & $\begin{array}{c}\text { Lettuc } \\
\mathbf{e}\end{array}$ \\
\hline & \multicolumn{7}{|c|}{ [g/plant] } \\
\hline T1 & 15.47 & 3.66 & 4.49 & 14.2 & 14.4 & 3.1 & 3.2 \\
\hline T2 & 15.00 & 3.33 & 3.76 & 11.13 & 12.57 & 5.37 & 4.2 \\
\hline T3 & 16.13 & 3.7 & 4.9 & 15.47 & 15.13 & 7.27 & 4.2 \\
\hline T4 & 11.23 & 3.04 & 4.15 & 14.73 & 13.6 & 6.3 & 5.3 \\
\hline T5 & 11.83 & 3.48 & 3.1 & 9.03 & 10.7 & 6.07 & 4.87 \\
\hline \multirow[t]{2}{*}{ L.S.D } & 0.4 & 0.05 & 0.03 & 0.9 & 0.9 & 0.015 & 0.74 \\
\hline & \multicolumn{7}{|c|}{ Second Season } \\
\hline \multirow[t]{2}{*}{ Treatment } & Bean & Cucumber & Tomato & Cantaloupe & Zucchini & Cabbage & $\begin{array}{c}\text { Lettuc } \\
\mathbf{e}\end{array}$ \\
\hline & \multicolumn{7}{|c|}{ [g/plant] } \\
\hline T1 & 16.83 & 3.69 & 4.52 & 14.25 & 14.5 & 3.2 & 3.27 \\
\hline T2 & 15.23 & 3.35 & 3.79 & 11.55 & 12.7 & 5.37 & 4.4 \\
\hline T3 & 19.57 & 3.75 & 4.95 & 15.52 & 15.36 & 7.37 & 4.2 \\
\hline T4 & 13.73 & 3.4 & 4.16 & 15.01 & 13.75 & 6.43 & 5.47 \\
\hline T5 & 13.67 & 3.52 & 3.12 & 9.4 & 11.08 & 6.2 & 5 \\
\hline L.S.D & 5.6 & 0.1 & 0.04 & 0.6 & 0.76 & 0.027 & 0.77 \\
\hline
\end{tabular}

Data in Table (5) showed the vegetative growth \&seedling dry weight which were during affected by different materials of nursery media, both growing seasons. It was observed that seedling parameters were found in T3 media (50\% (nursery $1+50 \%$ nursery2). This effect results were confirmed in both seasons, while the mixtures media T4 and T5 showed lower dry weight. It could be concluded that the greater amount of rice straw in nursery media had the lowest influence on seedling. This result was similar with Abdel Hamid et al. (2004). 
Table 5. Effect of different mixtures of rice straw media and peatmoss nursery media on dry weight $\mathrm{g} /$ plant of crop seedlings.

\begin{tabular}{|c|c|c|c|c|c|c|c|}
\hline & \multicolumn{7}{|c|}{ First Season } \\
\hline Treatment & Bean & Cucumber & Tomato & $\begin{array}{c}\text { Cantaloup } \\
\text { e }\end{array}$ & Zucchini & $\begin{array}{c}\text { Cabbag } \\
\text { e }\end{array}$ & $\begin{array}{c}\text { Lettuc } \\
\text { e }\end{array}$ \\
\hline T1 & 1.27 & 0.56 & 0.41 & 3.9 & 1.37 & 0.84 & 0.82 \\
\hline T2 & 1.23 & 0.52 & 0.41 & 3.2 & 1.33 & 0.94 & 0.84 \\
\hline T3 & 1.38 & 0.57 & 0.43 & 4.2 & 1.49 & 1.96 & 1.5 \\
\hline T4 & 1.2 & 0.47 & 0.38 & 2.67 & 1.3 & 1.7 & 0.96 \\
\hline T5 & 1.17 & 0.49 & 0.39 & 3.33 & 1.3 & 1.57 & 0.92 \\
\hline L.S.D & $\mathbf{0 . 0 1}$ & $\mathbf{0 . 0 0 3}$ & $\mathbf{0 . 0 0 2}$ & $\mathbf{0 . 1 2}$ & $\mathbf{0 . 0 7}$ & $\mathbf{2 . 8 4}$ & $\mathbf{0 . 0 0 1 4}$ \\
\hline & & \multicolumn{7}{|c|}{ Second Season } & & & \\
\hline Treatment & Bean & Cucumber & Tomato & $\begin{array}{c}\text { Cantaloup } \\
\text { e }\end{array}$ & Zucchini & e & e \\
\hline T1 & 1.4 & 0.56 & 0.43 & 3.94 & 1.43 & 0.83 & 0.83 \\
\hline T2 & 1.32 & 0.54 & 0.42 & 3.25 & 1.4 & 0.95 & 0.85 \\
\hline T3 & 1.55 & 0.58 & 0.43 & 4.35 & 1.54 & 1.97 & 1.53 \\
\hline T4 & 1.31 & 0.47 & 0.37 & 2.72 & 1.3 & 1.73 & 0.97 \\
\hline T5 & 1.13 & 0.49 & 0.41 & 3.39 & 1.35 & 1.6 & 0.94 \\
\hline L.S.D & $\mathbf{0 . 0 0 5}$ & $\mathbf{0 . 0 0 2}$ & $\mathbf{0 . 0 0 0 2}$ & $\mathbf{0 . 1}$ & $\mathbf{0 . 0 0 6}$ & $\mathbf{0 . 0 0 4}$ & $\mathbf{0 . 0 0 5}$ \\
\hline
\end{tabular}

Data in Table (6) indicate that seedling length of all studied plant species were significantly affected by rice straw media. The highest value was found with T3,(50\% nursery $1+<50 \%$ nursery2),followed by the control (T1100\% nursery 1 ) andT2 (25\% nursery $1+75 \%$ nursery 2$)$. However, the lowest value was found in $\mathrm{T} 4$ (75\% nursery $1+25 \%$ nursery2) followed by T5 (100\% nursery2). The same trend was found in the second season. This result agrees with Tamak et al.(1994). They found that rice straw at 5 or $10 \%$ concentrations significantly inhibited seed germination and seedling growth of oat compared with the control.

Table 6. Effect of different mixtures of rice straw media and peatmoss nursery media on crops seedling length $(\mathrm{cm})$.

\begin{tabular}{|c|c|c|c|c|c|c|c|}
\hline & \multicolumn{7}{|c|}{ First Season } \\
\hline Treatment & Bean & Cucumber & Tomato & $\begin{array}{c}\text { Cantaloup } \\
\mathbf{e}\end{array}$ & Zucchini & $\begin{array}{c}\text { Cabbag } \\
\mathbf{e}\end{array}$ & $\begin{array}{c}\text { Lettuc } \\
\mathbf{e}\end{array}$ \\
\hline T1 & 20.17 & 22.00 & 22.9 & 21.5 & 20.87 & 12.2 & 12.17 \\
\hline T2 & 20.3 & 20.26 & 21.69 & 19.5 & 20.20 & 13.27 & 14.00 \\
\hline T3 & 24.53 & 22.90 & 24.73 & 21.97 & 22.6 & 17.23 & 16.14 \\
\hline T4 & 21.07 & 19.2 & 21.12 & 21.3 & 21.4 & 15.37 & 15.2 \\
\hline T5 & 19.8 & 19.9 & 20.06 & 20.6 & 19.3 & 16.07 & 15.13 \\
\hline L.S.D & $\mathbf{1 . 8}$ & $\mathbf{0 . 2 8}$ & $\mathbf{0 . 5}$ & $\mathbf{1 . 0 4}$ & $\mathbf{0 . 2}$ & $\mathbf{0 . 0 1 6}$ & $\mathbf{0 . 0 1 5}$ \\
\hline \multicolumn{7}{|c|}{ Second Season } \\
\hline Treatment & Bean & Cucumber & Tomato & $\begin{array}{c}\text { Cantaloup } \\
\text { e }\end{array}$ & Zucchini & $\begin{array}{c}\text { Cabbag } \\
\text { e }\end{array}$ & $\begin{array}{c}\text { Lettuc } \\
\text { e }\end{array}$ \\
\hline T1 & 20.97 & 22.23 & 22.96 & 21.97 & 20.8 & 12.23 & 6.2 \\
\hline T2 & 16.77 & 20.67 & 21.74 & 19.33 & 20.13 & 13.27 & 6.3 \\
\hline T3 & 21.33 & 23.01 & 24.79 & 22.06 & 22.71 & 17.2 & 9.37 \\
\hline T4 & 19.3 & 19.95 & 21.03 & 21.26 & 21.52 & 15.37 & 7.33 \\
\hline T5 & 18.13 & 20.0 & 20.09 & 20.62 & 19.44 & 16.2 & 7.27 \\
\hline L.S.D & $\mathbf{0 . 7}$ & $\mathbf{0 . 2 6}$ & $\mathbf{0 . 4}$ & $\mathbf{1 . 1 6}$ & $\mathbf{0 . 1 6}$ & $\mathbf{0 . 0 0 9}$ & $\mathbf{0 . 0 1 9}$ \\
\hline
\end{tabular}


Table 7. Effect of different mixtures of rice straw media and peatmoss nursery media on seedling stem diameter $(\mathrm{cm})$.

\begin{tabular}{|c|c|c|c|c|c|}
\hline \multicolumn{6}{|c|}{ First Season } \\
\hline Treatment & Bean & Cucumber & Tomato & Cantaloupe & Zucchini \\
\hline T1 & 2.5 & 2.58 & 3.53 & 3.03 & 3.1 \\
\hline T2 & 1.23 & 3.43 & 3.48 & 3.9 & 3.23 \\
\hline T3 & 2.63 & 3.63 & 3.66 & 3.23 & 3.47 \\
\hline T4 & 1.93 & 3.02 & 3.15 & 2.9 & 3.07 \\
\hline T5 & 2.00 & 2.88 & 3.17 & 2.73 & 2.83 \\
\hline L.S.D & $\mathbf{0 . 0 6}$ & $\mathbf{0 . 0 0 3}$ & $\mathbf{0 . 0 0 1}$ & $\mathbf{0 . 0 2}$ & $\mathbf{0 . 6 5}$ \\
\hline \multicolumn{7}{|c|}{ Second Season } \\
\hline Treatment & Bean & Cucumber & Tomato & Cantaloupe & Zucchini \\
\hline T1 & 2.14 & 3.61 & 3.56 & 3.09 & 3.43 \\
\hline T2 & 1.83 & 3.47 & 3.51 & 2.92 & 3.37 \\
\hline T3 & 2.63 & 3.66 & 3.69 & 3.27 & 3.55 \\
\hline T4 & 2.4 & 3.09 & 3.15 & 2.97 & 3.11 \\
\hline T5 & 1.96 & 2.96 & 3.18 & 2.78 & 3.02 \\
\hline L.S.D & $\mathbf{0 . 0 2}$ & $\mathbf{0 . 0 0 3}$ & $\mathbf{0 . 0 0 2}$ & $\mathbf{0 . 4}$ & $\mathbf{0 . 0 1 3}$ \\
\hline
\end{tabular}

Data in Table (7) showed that, the effect of different mixtures between rice straw media and peatmoss nursery media on seedling stem diameter $(\mathrm{cm})$. There were significant differences among using different mixtures of rice straw media and peatmoss nursery media on crop seedling growth factors after 25 days from seeding date on stem diameter. The highest crop seedling stem diameter was obtained by $\mathrm{T3}$ in the both seasons and T1stem diameter than other treatment. However, the lowest value was found in T4 and T5 with increasing the rice straw in the mixture over $50 \%$, due to that plant stem diameter has been decreased. This agrees with Rizk et al. (2005) who reported that undiluted rice straw (Sakha 102) cultivar increased significantly the fresh weight of squash seedling.

Table 8. Effect of different mixtures of rice straw media and peatmoss nursery media onseedling average number of leaves and plant leaf area $\left(\mathrm{cm}^{2}\right)$.

\begin{tabular}{|c|c|c|c|c|}
\hline & \multicolumn{4}{|c|}{ First Season } \\
\hline & \multicolumn{2}{|c|}{ Cabbage } & \multicolumn{2}{|c|}{ Lettuces } \\
\hline Treatment & $\begin{array}{c}\text { Average } \\
\text { Number of } \\
\text { leaves }\end{array}$ & $\begin{array}{l}\text { Leaves area } \\
\qquad\left(\mathrm{cm}^{2}\right)\end{array}$ & $\begin{array}{c}\text { Average } \\
\text { Number of leaves }\end{array}$ & Area leaves $\left(\mathrm{cm}^{2}\right)$ \\
\hline T1 & 3.2 & 7.00 & 2.67 & 6.17 \\
\hline T2 & 4.2 & 8.03 & 2.67 & 6.03 \\
\hline T3 & 6.14 & 10.03 & 4.67 & 9.23 \\
\hline $\mathrm{T4}$ & 5.53 & 9.07 & 3.67 & 7.1 \\
\hline T5 & 5.23 & 9.13 & 3.67 & 7.07 \\
\hline \multirow[t]{3}{*}{ L.S.D } & 0.02 & 0.005 & 0.22 & 0.016 \\
\hline & \multicolumn{4}{|c|}{ Second Season } \\
\hline & \multicolumn{2}{|c|}{ Cabbage } & \multicolumn{2}{|c|}{ Lettuces } \\
\hline Treatment & $\begin{array}{c}\text { Average } \\
\text { Number of } \\
\text { leaves }\end{array}$ & $\begin{array}{l}\text { Leaves area } \\
\left(\mathrm{cm}^{2}\right)\end{array}$ & $\begin{array}{c}\text { Average } \\
\text { Number of leaves }\end{array}$ & Area leaves $\left(\mathrm{cm}^{2}\right)$ \\
\hline $\mathrm{T} 1$ & 3.3 & 7.23 & 2.67 & 6.2 \\
\hline T2 & 4.3 & 8.2 & 2.67 & 6.3 \\
\hline T3 & 6.27 & 10.2 & 3.67 & 9.37 \\
\hline T4 & 5.5 & 9.23 & 3.33 & 7.33 \\
\hline T5 & 5.33 & 9.33 & 3.67 & 7.27 \\
\hline L.S.D & 0.005 & 0.008 & 0.16 & 0.019 \\
\hline
\end{tabular}


Data in Table (8) showed the effect of different growing media composition on all seedling average number of leaves and plant leaf area $\left(\mathrm{cm}^{2}\right)$. It was observed that seedling characteristics were the best with T3. This result was confirmed in both seasons. The lowest value was found in T4 and T5with increasing the rice straw in the mixture over $50 \%$ the fresh weight decreased. It could be concluded that the greater amount of rice straw in nursery media caused this influence on cucumber seedling characteristics.

Table 9. Effect of different mixtures of rice straw media and peatmoss media on the nitrogen content of seedlings of (the dry matter \%).

\begin{tabular}{|c|c|c|c|c|c|c|c|}
\hline \multirow{3}{*}{ Treatment } & \multicolumn{7}{|c|}{ First Season } \\
\hline & Bean & Cucumber & Tomato & Cantaloupe & Zucchini & Cabbage & Lettuce \\
\hline & \multicolumn{7}{|c|}{$[\mathrm{N} \%]$} \\
\hline $\mathrm{T} 1$ & 2.9 & 3.8 & 3.13 & 4.00 & 3.27 & 3.27 & 3.27 \\
\hline $\mathrm{T} 2$ & 2.5 & 3.7 & 3.03 & 4.03 & 2.93 & 2.93 & 2.93 \\
\hline T3 & 2.23 & 4.14 & 3.41 & 4.17 & 3.77 & 3.77 & 3.77 \\
\hline T4 & 2.7 & 3.18 & 2.93 & 3.89 & 2.87 & 2.87 & 2.87 \\
\hline T5 & 2.73 & 3.00 & 2.8 & 3.6 & 2.96 & 2.96 & 2.96 \\
\hline \multirow[t]{2}{*}{ L.S.D } & 0.03 & 0.002 & 0.003 & 0.01 & 0.02 & 0.02 & 0.02 \\
\hline & \multicolumn{7}{|c|}{ Second Season } \\
\hline \multirow{2}{*}{ Treatment } & Bean & Cucumber & Tomato & Cantaloupe & Zucchini & Cabbage & Lettuce \\
\hline & \multicolumn{7}{|c|}{$[\mathrm{N} \%]$} \\
\hline $\mathrm{T} 1$ & 2.96 & 3.83 & 3.25 & 3.1 & 3.48 & 3.48 & 3.48 \\
\hline $\mathrm{T} 2$ & 2.41 & 3.74 & 3.16 & 4.09 & 3.07 & 3.07 & 3.07 \\
\hline T3 & 3.19 & 4.21 & 3.44 & 4.2 & 3.85 & 3.85 & 3.85 \\
\hline $\mathrm{T} 4$ & 2.9 & 3.22 & 2.98 & 3.63 & 2.93 & 2.93 & 2.93 \\
\hline T5 & 2.73 & 3.05 & 2.83 & 3.61 & 3.00 & 3.00 & 3.00 \\
\hline L.S.D & 0.04 & 0.004 & 0.005 & 0.53 & 0.008 & 0.008 & 0.008 \\
\hline
\end{tabular}

Table 10. Effect of different mixtures of rice straw media and peatmoss nursery media on the phosphorus content of seedlingsof (the dry matter \%).

\begin{tabular}{|l|c|c|c|c|c|c|c|}
\hline \multicolumn{1}{|c|}{} & \multicolumn{7}{|c|}{ First Season } \\
\hline Treatment & Bean & Cucumber & Tomato & Cantaloupe & Zucchini & Cabbage & Lettuce \\
\hline T1 & 0.21 & 0.24 & 0.36 & 0.29 & 0.23 & 0.23 & 0.23 \\
\hline T2 & 0.13 & 0.21 & 0.41 & 0.27 & 0.16 & 0.16 & 0.16 \\
\hline T3 & 0.19 & 0.29 & 0.51 & 0.6 & 0.26 & 0.26 & 0.26 \\
\hline T4 & 0.18 & 0.22 & 0.45 & 0.5 & 0.25 & 0.25 & 0.25 \\
\hline T5 & 0.21 & 0.21 & 0.43 & 0.3 & 0.23 & 0.23 & 0.23 \\
\hline L.S.D & 0.0003 & 0.0001 & 0.001 & 0.001 & 0.003 & 0.003 & 0.003 \\
\hline & \multicolumn{7}{|c|}{ Second Season } \\
\hline Treatment & Bean & Cucumber & Tomato & Cantaloupe & Zucchini & Cabbage & Lettuce \\
\hline T1 & 0.23 & 0.26 & 0.38 & 0.31 & 0.26 & 0.26 & 0.26 \\
\hline T2 & 0.17 & 0.24 & 0.42 & 0.27 & 0.22 & 0.22 & 0.22 \\
\hline T3 & 0.24 & 0.31 & 0.52 & 0.35 & 0.27 & 0.27 & 0.27 \\
\hline T4 & 0.18 & 0.24 & 0.46 & 0.24 & 0.22 & 0.22 & 0.22 \\
\hline T5 & 0.19 & 0.23 & 0.44 & 0.22 & 0.21 & 0.21 & 0.21 \\
\hline L.S.D & 0.0001 & 0.0001 & 0.0006 & 0.0001 & 0.002 & 0.002 & 0.002 \\
\hline
\end{tabular}


Table 11. Effect of using different mixtures of rice straw media and peatmoss nursery media on the potassium content of seedlings of (the dry matter \%)

\begin{tabular}{|c|c|c|c|c|c|c|c|}
\hline & \multicolumn{7}{|c|}{ First Season } \\
\hline Treatment & Bean & Cucumber & Tomato & Cantaloupe & Zucchini & Cabbage & Lettuce \\
\hline T1 & 2.27 & 3.72 & 5.13 & 3.23 & 2.4 & 2.4 & 2.4 \\
\hline $\mathrm{T} 2$ & 1.93 & 3.2 & 4.93 & 3.02 & 2.43 & 2.43 & 2.43 \\
\hline T3 & 2.67 & 3.8 & 5.93 & 3.67 & 2.73 & 2.73 & 2.73 \\
\hline T4 & 1.97 & 3.00 & 4.86 & 2.8 & 2.44 & 2.44 & 2.44 \\
\hline T5 & 2.1 & 2.91 & 4.7 & 2.53 & 2.23 & 2.23 & 2.23 \\
\hline \multirow[t]{2}{*}{ L.S.D } & 0.019 & 0.005 & 0.01 & 0.02 & 0.008 & 0.008 & 0.008 \\
\hline & \multicolumn{7}{|c|}{ Second Season } \\
\hline Treatment & Bean & Cucumber & Tomato & Cantaloupe & Zucchini & Cabbage & Lettuce \\
\hline $\mathrm{T} 1$ & 2.25 & 3.75 & 5.24 & 3.23 & 2.58 & 2.58 & 2.58 \\
\hline T2 & 2.17 & 3.26 & 4.96 & 3.07 & 2.48 & 2.48 & 2.48 \\
\hline T3 & 2.93 & 3.9 & 5.93 & 3.72 & 2.93 & 2.93 & 2.93 \\
\hline T4 & 1.97 & 3.05 & 4.82 & 2.84 & 2.43 & 2.43 & 2.43 \\
\hline T5 & 2.5 & 2.94 & 5.74 & 2.55 & 2.31 & 2.31 & 2.31 \\
\hline L.S.D & 0.008 & 0.006 & 0.5 & 0.03 & 0.008 & 0.008 & 0.008 \\
\hline
\end{tabular}

Data in Tables (10) and (11) showed the effect of different growing media on the seedling NPK content. The analysis indicated that NPK contents were increased with T3 media. This effect was confirmed in both seasons. While the seedlings in media T4 and T5 were lower NPK content values. The same trend was found in the second season. Rice straw is rich in $(\mathrm{C})$ and poor in $(\mathrm{N})$. The $(\mathrm{C} / \mathrm{N})$ ratio can vary from 50 to 150 , which limits the composting process. This high $\mathrm{C} / \mathrm{N}$ ratio can be decreased by increased the $\mathrm{N}$ content of rice straw by adding manure, which is available in Egypt. The composting of rice straw together with poultry manure and the effect of this compost on soil properties were studied in pot experiments by

Abdel Hamid et al. (2004) in Thailand. They have found that the chemical properties of this organic media were comparable to that of commercial inorganic and organic media as described in earlier studies (Amassa and Manenoi, 2008). 


\section{CONCLUSIONS}

Rice straw is the only organic material that is available in a huge quantity at the most of the farms in Egypt. Currently this straw acts as wastes for the farmers that need a solution to get rid of it. Therefore, the results of this research contribute to a solution by using rice straw as a nursery media. Therefore, the phenomena of burning the rice straw can be reduced. The use of rice straw as alternative agriculture media, could reduce the import of peat moss at the same time this method is easy to implement, the preparation of such nursery medias cheaper than conventional media. Compared with the composting of straw the preparation time is short. But the results showed, that a complete replacement of peat moss media by chopped rice straw as nursery media could cause negative effects to the seedlings.

\section{AKNOWLEGMENTS}

Authors would like to introduce their gratitude and great thanks to Academy of Scientific Research and Technology, for supporting this investigation by GERF II, STDF, ARC, CEMUWA project 3145. Also, great thanks are presented to the Rostock University team join the project for their kindly support and cooperation.

\section{REFERENCES}

1. Abdel Hamid, M.T., T. Horiuchi and S.Oba. 2004. Composting of rice straw with oilseed rape cake and poultry manure its effects on Saba bean (Viciafaba L) growth and soil properties. Bioresourc -Technol. 93 (2): 183 -189.

2. Agriculture Extension Bulletin. 1993. Production of vegetable seedlings under protected agriculture. Protected Agriculture Project, UNDP-FAO, Ministry of Agriculture and Land Reclamation., ARC, MALR Agric. Exten. Bull. No. 1. 1993.

3. A.O.A.C. 1991. Association of official methods of analytical chemists, official methods of analysis 15 th ed. Washington, D.C., U.S.A.

4. Badran, N.M., El-Hussieny, O.H. and Allam, E.H. 2007. Efficiency of some natural substitutes of peatmoss as growing media for tomato seedling production. Australian J. Basice \& App. Sci, Vol. 1(3), pp. 193-207.

5. Baiyeri, K.P. 2005. Response of Musa Species to Macro Propagation: II: The effects of genotype, initiation and weaning media on sucker growth and quality in the nursery. Afr. J. Biotechnol. 4(3): 229-234. 
6. Baiyeri, K.P., and B. N. Mbah : 2006. Effects of soilless and soil based nursery media on seedling emergence, growth and response to water stress of African breadfruit (Treculia Africana Decne). Afr. J. Biotecnol., 5: 1405-1410.

7. Dobermann, A. and T.H. Fairhurst, 2002. Rice Straw Management. Better Crops International. 16: Special Supplement.

8. Hartmann H. T., D.E. Kester,. F.T. Davies., and R. I. Genve, R. I., 2007. Hartmann and Kester's plant propagation, principles and practices.Seventh edition.Prentice-Hall of India Private limited pp880.

9. Hassan, I.A. 2005. Effect of rice straw compost and water regimes on growth performance of tomato (LycopersicumEsculentum L.). PhD thesis.Faculty of Agriculture, Universiti Putra Malaysia.

10. Manenoi , A ., W. Tamala, A. Tunsungnern and A. Amassa . 2009. Evaluation of an on-farm organic growing media on the growth and development of pepper seedlings. As. J. Food Ag-Ind., Special Issue, S75-S80

11. Ranganna, S. 1979. Manual analysis of fruit and vegetable products. Data Magrow Hill Publishing Company Limited New Delhi 634p.

12. Rizk, T.Y., M.M.F. Abdallah, N.M.Mahrous and M.A. Abd- Elaziz. 2005. Allelopathic effect of rice straw and stubble extracts on seed germination and seedling growth of squash, pea and tumip. J. Environ. Sci., 11 (1) : 199-219.

13. Snedicor, R.G. and W.G. Cochran, 1980.Statistical methods.sixth edition, Iowa State Univ. Press, Amer. Iowa,USA.

14. Tamak, J.C; S.S. Narwal, and L. Singh, 1994. Effect of aqueous extracts of rice stubbles and straw + stubbles on the germination and seedling growth of wheat. Crop Res. (Hisar), 8(1): 180-185.

15. Wilson S.B.,L.K. Mecca, H.E. Danielson, D.A. Graetz, and P.J. Stoffella , 2006. Container and field evaluation of three native shrubs grown in compost-based media. Compost Sci. \& Utiliz. 14 , 178-183. 


\section{مقارنة بين البيتموس وقش الارز كبيئة للمشتل}

\section{منال محمد حسنى جاد المولى' ، احمد عونى فرج '، منى على محمد على' ، طارق محمد زين يونس 'و اندريا شوش'}

$$
\text { | المعهل المركزى للمناخ الزراعى - مركز البحوث الزراعية }
$$

r r جامعات روستوك- كلية الزراعة و البيئة- قسم ادارة المخلفات و تنفق الموارد - المانيا

يعد قش الارز من أحد المخلفات النباتية الزراعية والتى يجب التخلص منها وتوجد عدة

اقترحات لاستخدام قش الارز فى مجال الزراعة ويهدف البحث الى امكانية الحصول على بيئة عضوية رخيصة الثمن وذات خو اص طبيعية وكيمائية تتاسب نمو مختلف النباتات مثل انتاج شتلات الخضر .تم اجر اء التجربة بلمعمل المركزى للمناخ الزراعى ، مركز البحوث الزر اعية داخل صوبة وده

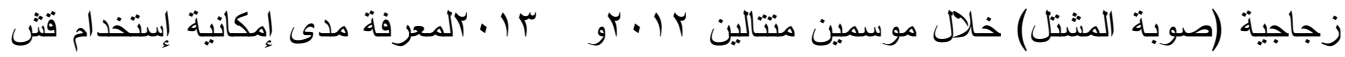
الارز كبيئة عضوية لزراعة شتلات كلا من الفاصوليا - خيار - كانتالوب- كوسة - طماطم كرنب وخس ومقارناتها ببيئة البيتموس و التى تحتوى على البيتموس: الفرموكوليت بنسبة إ:ا

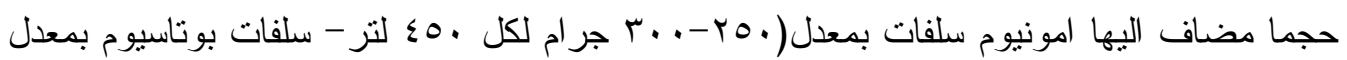

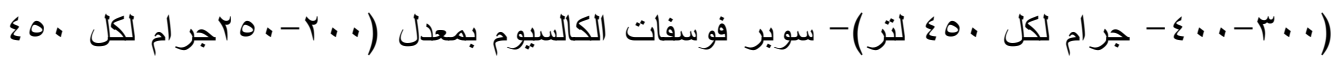

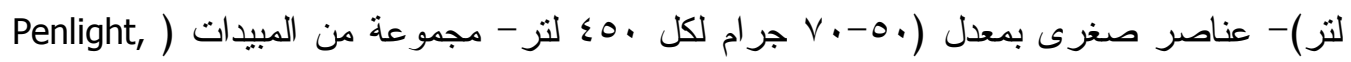
( Vetafax, Kapetan, Rizolex

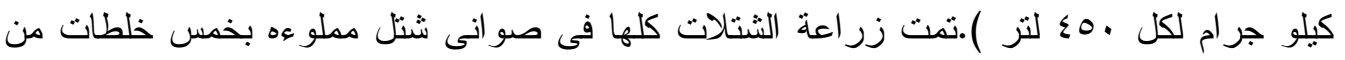

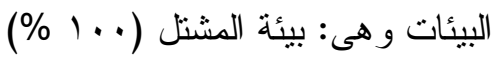

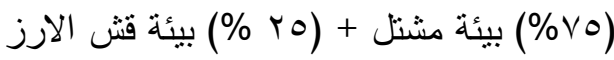

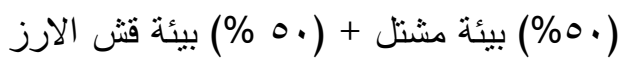

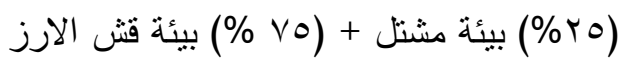

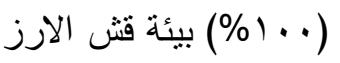

وذللك فى ثناث مكرارت. وقد تم اخذ القياسات الخضرية على الثتلة وهى قطر الثتلة -

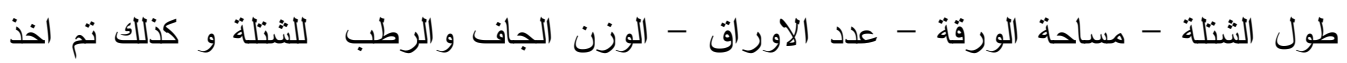

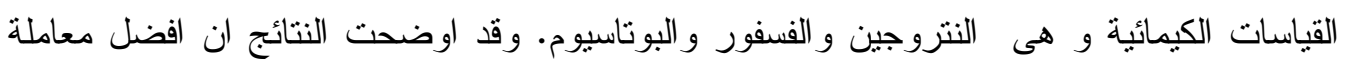
كانت (0 \% \%) بيئة مشتل + (0 \% \% ) بيئة قش الارز . 